\title{
2002 Sonrası Milli Parklar Kanunu Kapsamında İlan Edilen Doğa Koruma Alanlarına Eleştirel Bir Bakış
}

\author{
Critical Outlook on Nature Protection Areas Which Announced \\ According to 2873 National Park Law After 2002
}

\section{Gencay Serter}

Tarım ve Orman Bakanlığı, Doğa Koruma ve Milli Parklar Genel Müdürlüğü, Ankara

\section{ÖZ}

Neoliberal politikalar, birçok alanda olduğu gibi doğa koruma alanında da yıkım yaratan bir süreci ortaya çıkarmışlardır. Ancak bu sonuçlar toplumun değişik kesimleri tarafından birbirinden farkIı biçimde algılanmış ve yorumlanmıştır. Türkiye'de de neoliberal politikaların en katıksız ve sert uygulandığı dönem olarak 2002 sonrası süreçte; doğa koruma alanında yapılan uygulamalar, siyasi temsilciler ve ortaya çıkan politikaların uygulayıcıları bürokratlar tarafından farklı biçimde yorumlanırken; doğa koruma alanında faaliyet gösteren STK'lar, meslek odaları ve bir kısım sivil halk tarafından tam tersi şekilde açıllanmış ve yoğun şekilde eleştiriye tabi tutulmuştur. Makale kapsamında bu farklılıkları nesnel ve objektif bir şekilde ortaya koymak için korunan alanların 2002 sonrasında hem nicel hem de nitel açıdan değişimi incelenmiştir. Bu kapsamda 2002 sonraki süreçte 2873 sayılı Milli Parklar Kanunu uyarınca ilan edilen korunan alanlarda (Tabiatı Koruma Alanı, Milli Park, Tabiat Parkı ve Tabiat Anıtı) ortaya çıkan niceliksel değişimlerin, korunan alanlarla ilgili olarak kabul görmüş uluslararası kıstaslar çerçevesinde nitelik açısından gerçekten ne ifade ettiği ve nasıl bir sonuç ortaya koyduğu belirlenmeye çalışılmıştır. Bu şekilde 2002 sonraki süreçte korunan alanlarla ilgili olarak çoğu zaman basit bir istatistik veri olarak ele alınan ve tartışmalara yol açan değişimlerin, Türkiye özelinde doğa koruma açısından gerçek anlamda nasıl bir sonuç yarattığı nesnel bir çerçevede ortaya konulmaya çalışılmıştır.

Anahtar sözcükler: Korunan alan; milli park, tabiat anıtı; tabiat parkı; tabiatı koruma alanı.

\begin{abstract}
Neoliberal politics revealed the process which creates the destruction in nature protection area just like in the orher areas. However, these consequences are perceived and interpreted differently by the people from different parts of the society. Although practices in the nature conservation sector were interpreted by political actors and beurocrats as the practitioners of these politics in different way; but NGO's, proffesional chambers and some of the civil society interpreted these politics in the exact opposite way and criticised intensively in post-2002 period which is the period contains pure neoliberal practices. In this article, in order to evaluate differences in practical and objective way, quantitative changes related conservation areas evaluated together with qualitative changes. With in this scope, quantitative changes according to international criterias evaluated with qualitatif changes about declerated conservation areas according to 2873 National Park Act (National Park, Nature Conservation Areas, Nature Park, Nature Monumet). After 2002, changes about protected areas usually evaluated as a simple statistical data. But actually data about conservation areas are always controversial in Turkey. By this way, consequences of these changes to Turkey evaluated in this article from the point of nature protection.
\end{abstract}

Keywords: Protected area; national park; nature monument; nature park; nature conservation area. 


\section{Giriş}

İnsan faaliyetleri neticesinde ekolojik bir yıkıma doğru ilerleyen dünyamızda doğa koruma her geçen gün üzerine daha çok vurgu yapılan ve öne çıkan kavram haline gelmiştir. Dünyanın geldiği bu kritik eşikte korunan alanlar, türleri ve biyoçeşitliliği korumak açısından en önemli ve etkili araçlardan biri olarak görülürken (Bruner vd., 200I; Mace, 1998) diğer taraftan da bu alanların kültürel, jeolojik, tarihi ve peyzaj değerlerin korunmasında büyük katkı sağladıklarının altı çizilmektedir (Gülez, 1992; Eagle vd., 2002). Bu özellikleri sebebiyle tüm bu değerleri korumak anlamında korunan alanların sayıca ve alansal olarak artırılmasının birincil strateji olması gerektiği genel kabul gören bir önermedir (Liu vd., 20l0).

Ancak korunan alanlardaki sayısal artışın aynı zamanda nitelik açısından bir artış anlamına gelip gelmediği tüm dünyada olduğu gibi ülkemizde de bir tartışma konusudur. Bu noktada neoliberal politikaların en katıksız ve sert uygulandığı dönem olarak 2002 sonrası doğa koruma alanında yapılan uygulamalar siyasi iktidar tarafından "devrim”, "atılım” gibi sıfatlarla tanımlanırken; içerisinde bazı yerel halk, STK'lar ve meslek odalarının bulunduğu kesimler tarafından ise bu süreç tam tersi şekilde tanımlanmış ve yoğun biçimde eleştiriye tabi tutulmuştur.

Bu makale tam da bu noktada doğa koruma alanları özelinde yaşanan değişim ve dönüşüm sürecinin nesnel verilere bağlı kalarak objektif bir değerlendirmesini yapmayı hedeflemektedir. Bu amaç doğrultusunda 2002-2018 arasındaki süreçte 2873 sayılı Milli Parklar Kanunu uyarınca belirlenen korunan alanlarda yaşanan sayısal artışın doğa koruma hedefi açısından nitelikli bir artış yaratıp yaratmadığı ortaya konulmaya çalışılacaktır.

\section{Çalışmanın Hipotezi}

Neoliberalizm kurgusu gereği sermayenin birikim ve dolaşım hızını artırmayı amaçlayan bir ideoloji olarak, özel mülkiyet ağının yaygınlaştırılmasını; buna karşılık kamusal kullanım ve alanların oranının ise sürekli azaltılmasını amaçlamaktadır. Bu çerçevede neoliberalizm serbest piyasa işleyişinin en üst seviyede hayata geçirilmesi için her şeyin piyasalaştırılmasını ve metalaştırılmasını hedeflemektedir. Bu kurgu içerisinde sermayenin birikim döngüsünde en önemli bileşenlerden biri olarak doğanın, bu işleyişten ari kalacağını düşünmek gerçekçi bir yaklaşım olmayıp, eşyanın doğasına aykırıdır.

Türkiye'de de neoliberal politikaların en katıksız biçimde uygulandığı 2002-2018 arası süreçte; elde ettiği tek başına iktidar yetkisiyle sürecin yürütücüsü olan Adalet ve Kalkınma Partisi yöneticileri tarafından, 2002 sonrasında korunan alanların miktarının arttığı, korunan alanlarda önceki süreçlerle kıyaslandığında büyük atılımların gerçekleştiği kamuoyunda sürekli biçimde ifade edilmiştir. Ancak, ekonomik kalkınmayı politikalarının en başat unsuru haline getiren; hatta ekono- mik kalkınma senaryoları içerisinde en yıkıcı olanlarından biri olarak inşaata dayalı gelişme senaryosunu seçen; siyasi popülizmi etkin şekilde kullanan parti olarak Adalet ve Kalkınma Partisi'nin bu söylemlerinin gerçeği ne kadar yansıttığı test edilmeye muhtaçtır.

Bu anlamda çalışma, iddia edilenin aksine doğal karakterinden ötürü ilan edilen korunan alanlardaki niceliksel artışın belirtildiği kadar yüksek olmadığı ve koruma statülerinin değiştirilmesi suretiyle korunan alanlarda niteliksel anlamda bir düşüşün yaşandığı hipotezine dayanmaktadır.

Çalışmada bu hipotez uluslararası ve ulusal ölçekte belirlenen kriterler çerçevesinde yapılan değerlendirmelerle test edilmiştir. Ayrıca hipotezin daha geniş ölçekte geçerliliğini doğrulamak için çalışmanın zamansal sınırını oluşturan 2002-2018 arasındaki süreç içerisinde, Türkiye'de doğa koruma alanında ortaya çıkan gelişmeler, Avrupa ülkeleri ile niceliksel anlamda karşılaştırmalı şekilde ortaya konulmuştur.

\section{Çalışma Alanı ve Sınırlııklar}

Korunan alan tanımı oldukça geniş bir çerçeveye sahiptir. $\mathrm{Bu}$ geniş alana ilişkin olarak ülkemizde korunan alanlarla ilgili iş ve işlemler birçok bakanlığın idari sorumluluğu altında ve geniş bir mevzuat çerçevesinde yürütülmektedir. Korunan alanlar içerisinde bir alt dal olarak tanımlayabileceğimiz doğal nitelikli korunan alanlar da benzer biçimde oldukça geniş bir fiziki coğrafyayla birlikte karmaşık kamusal yapı ve işleyişi içerisinde barındırmaktadır. Dolayısıyla bu tür alanlara ilişkin bir değerlendirme yapabilmek için belirsizlik yaratan değişkenlerin sınırlandırılması gerekmektedir. Bu çalışma dâhilinde de tarihsel, mekânsal ve idari anlamda bir sınırlandırma yapmak zorunlu hale gelmiştir.

Doğal karakterinden ötürü ilan edilen korunan alanlar içerisinde en fazla yüzölçümüne sahip olan statü doğal sit alanlarıdır. Sit alanlarının hepsi 2002 tarihinde tek bir bakanlığın yetkisi altındayken daha sonrasında bu alanlara ilişkin yetki iki kuruma dağıtılmış; arkeolojik, tarihi ve kentsel sitler Kültür ve Turizm Bakanlığı'nın, doğal sitler ise Çevre ve Şehircilik Bakanlığı'nın yetkisi altına girmiştir. İdari anlamda köklü değişikliklerin yapıldığı sit alanları, hem sayısal olarak belirli istatistiklerin tutulmasının zor olması, hem de içerisinde doğal alan olarak değerlendirilemeyecek kullanımlara (akaryakıt istasyonu, madencilik faaliyeti, sanayi tesisleri, katı atık depolama üniteleri vb.) izin verilmesi sebebi ile çalışma alanı dışında tutulmuştur.

Ancak 2873 sayılı kanunda sayılan tabiatı koruma alanı, milli park, tabiat parkı ve tabiat anıtları I I.08.1983 tarihinden bu zamana aynı kanunla yönetilen ve diğer korunan alan türleri ile kıyaslandığında yasal ve idari değişikliklerden en az etki- 
lenmiş; doğal karakteri daha yüksek olan korunan alanlardır. Dolayısıyla niteliksel ve niceliksel kıyaslamaları net şekilde ortaya koymak için idari ve hukuki çerçevede en az değişikliğe uğramış; doğa koruma hedefi diğer korunan alanlarla kıyaslandığında daha üst ölçekte ele alınan 2873 sayılı kanun dâhilindeki korunan alanlar bu çalışmada değerlendirmeye alınmıştır. Zamansal olarak ise Adalet ve Kalkınma Partisi'nin iktidarda olduğu 2002-20 I 8 yılları arası dönem zamansal sınırı oluştururken, mekânsal anlamda ise çalışma verileri tüm Türkiye genelinden toplanmıştır.

\section{Dünyada ve Türkiye'de Doğa Koruma Alanlarının Gelişimi}

Doğa korumaya yönelik girişimlerin geçmişi insanlık tarihi kadar eskiye gitmektedir. İnsan-doğa ilişkisinin günümüzdeki kadar yıkıcı olmadığı, doğa karşısında günümüzle kıyaslandığında kendini daha edilgen hissettiği çağlarda, insanlar doğaya kutsallık addetmişler ve ilk doğa koruma alanları kutsal alanlar olarak ortaya çıkmışlardır. Bu anlamda Güney Hindistan'daki, kutsal kabul edilen Tamil Nadu koruluklarının korunmasının yontma taş ve cilalı taş devirlerindeki ilk koruma olayı olduğu düşünülmektedir (Krishna ve Sankar, 1997). Dünya Doğayı Koruma Vakfı da 2005 raporunda kutsal yerlerin bugün bildiğimiz anlamda kurumsal ve resmi olarak tanımlanan korunan alanlardan önce insanlık tarafından ilk kez koruma altına alınan ve bugün için gezegen üzerinde birçok örneklerine rastlanabilen habitat koruma alanları olduklarının altını çizmiştir (Wild ve Leod, 2008).

Doğa koruma alanında, doğaya addedilen kutsallıklar çerçevesinde biçimlenen birinci aşamadan sonra ikinci aşama tür koruma üzerinden şekillenmiştir. Bu anlamda 1250 yılında İngiltere'de ilk kez kartal, doğan, atmaca ve balıkçıl kuşlarının korunması yönünde çabalar gündeme gelmiştir (Ant ve Stipprowet, 1985). Tür korumadan öte alan korumasına yönelik kapsamlı ilk uygulama ise Hollanda'da ortaya çıkmıştır. Peyzaj güzelliği, flora ve fauna zenginliği ve halkın belirli süre dahilinde yararlanması amacıyla Hollanda'da 1576 yılında Prens ve Vali, Lahey ormanının korunması konusunda anlaşmışlardır. Yine İngiltere'de 18. ve 19. yy'larda soylu sınıfın statü göstergesi olarak gördüğü ve avcılık faaliyetlerini sürdürdükleri belirli ormanlık alanlar koruma altına alınmışlardır (Kurdoğlu, 2007: 6I).

Benzer biçimde Amerika'da da soylu sınıfın ayrıcalıklı şekilde kullanımına ayrılmış, halkın girişinin kısıtlandığı 2500 hektardan küçük 500 kadar yaban hayatı koruma alanı ayrılmıştır. Ancak kendisi yazar ve ressam olan George Catlin, sadece soylu sınıfının kullanımına yönelik eleştiriyi gündeme getirmiş ve Yellowstone ve Missorui nehrinin kesiştiği bölgedeki güzellikten etkilenerek "bu yerin tüm tazeliği, doğallığı, insan ve tüm canlılarıyla birlikte ulusun parkı (nation's park)" olarak ilan edilmesini teklif etmiştir (Kurdoğlu, 2007: 6I). Akabinde
Yellowstone Milli Parkı (1872) tüm halkın ortak gönenci ve faydalanabilmesi amacıyla ilan edilen ilk milli park olmuştur.

Geniş coğrafyaların korunan alan olarak ilan edilerek korunması fikri daha çok yine ağırlıkla Amerika kıtasında ve Avustralya'da yaygınlaşmıştır. Daha sonra Avrupa kıtasına yayılan bu anlayış neticesinde; 1909 yılında İsveç, 19|4 yılında da İsviçre'de ilk milli parklar ilan edilmişlerdir. Ancak ilan edilen korunan alanların kullanım amaçları ve kurguları ülkelerin kendi özgün koşullarına göre oldukça farklılaşmıştır. Korunan alan düşüncesi Kuzey Amerika'da sıkı koruma güdüsü ile gündeme gelirken, Afrika'da oyun parkları, Avrupa'da ise peyzaj koruma alanları biçiminde ortaya çıkmıştır (Phillips, 2017: 12). Amerika'da milli park anlayışı büyük doğal alanların ziyaretçilere kapatılarak korunması üzerine kurgulanmışken, Avrupa da ise bambaşka bir ekol çerçevesinde milli parklar insan-doğa ilişkisinin ön plana alındığı; bilimsel araştırmaların yanında, ziyaretçilerin doğaya zarar vermeden turistik amaçlı kullanımına olanak verecek alanlar biçimde ele alınmışlardır (Yücel ve Babuş, 2005:7).

Tüm dünya üzerinde hızla yaygınlaşan korunan alanlar farklı amaçlar ve yöntemler doğrultusunda ilan edilirken; bu alanların sınıflandırılması ve belirli kriterlere bağlı olan tanımlanmaları ihtiyaç haline gelmiştir. Bu ihtiyaç doğrultusunda Uluslararası Doğayı Koruma Birliği (IUCN) 1948 tarihinde kamusal ve sivil toplum niteliğindeki birlik olarak kurulmuştur. 1972 yılında 2. Dünya Parklar Kongresi'nde IUCN “değişik amaçlar için ayrılmış korunan alanlarla ilgili olarak standartlar ve terminolojiyi geliştirmek" için göreve çağrılmış (Elliot, 1974) ve IUCN'in hazırladığı rapor sonucunda korunan alanlara ilişkin 1978 tarihinde 5 temel kategoriye (Bilimsel Rezerv, Milli Park, Tabiat Anıtı/ Ulusal Simge (Landmark), Tabiatı Koruma Rezervi, Peyzaj Koruma Alanı) dayanan sistematik geliştirilmiştir. Sürekli yenilenen bu sınıflandırma sistemi en son IUCN'in 1994 yılında Buenos Aires'te düzenlenen Genel Kurulu'nda bugün için de hala geçerli olan ve en geniş anlamda kabul gören 6 sınıftan oluşan sistematiğe dönüşmüştür (Jongman, 2004).

Ülkemizde ise doğa koruma anlamında büyük ölçekli korunan alan ilan süreci 1958 yılında Yozgat Çamlığı Milli Parkı ile başlamıştır. $O$ tarihten itibaren dünyadaki gelişmelere paralel biçimde koruma ihtiyacını yönlendiren farklı ihtiyaçlara göre birçok kurum tarafından ve farklı statülerle doğa korumaya yönelik alanlar ilan edilmiş ve bu alanlara yönelik mevzuatlar oluşturulmuştur. Günümüzde doğal alanlarla ilgili olarak sit alanları ve özel çevre koruma bölgeleri Çevre ve Şehircilik Bakanlığı'nın yetkisindeyken; 2873 sayılı kanun uyarınca ilan edilen tabiatı koruma alanı, milli park, tabiat parkı ve tabiat anıtları ise Tarım ve Orman Bakanlığı'nın yetkisinde bulunmaktadır. Bu alanların yanında Tarım ve Orman Bakanlığı tarafından muhafaza ormanı, gen koruma ormanı, kent ormanları ve tohum mesçereleri gibi sahalar da korunan alan olarak değerlendirilmektedir. Oysa korunan alan olarak sayılan bu 
alanların birçoğu ilan ve yönetim amacı açısından korunan alan anlayışıyla uyuşmayan alanlardır.

Bu çerçevede incelendiğinde kent ormanları birçok zaman, plantasyon uygulamaları ile ağaçlandırma sonucu oluşturulan sahalar olup, bu alanlar da temel hedef korumadan çok; halkın günübirlik rekreasyon ihtiyaçlarını karşılamaktır. Muhafaza ormanları ise esasen başka bir yapıyı korumak, ülke güveliğini sağlamak veya belirli bir doğa olayına engel olmak amacıyla korunan ormanlık alanlar olarak ilgili mevzuat içerisinde tanımlanmıştır (http://www.mevzuat.gov.tr/MevzuatMetin/l.3.683 I. pdf, Erişim Tarihi: 23.07.2018). Dolayısıyla bir alan muhafaza ormanı olarak belirlenirken temel gaye esasen muhafaza ormanının kendisinden öte koruduğu alan veya engel olmaya çalışılan bir doğa olayıdır. Tarım ve Orman Bakanlığı tarafından korunan alan olarak sayılan gen koruma ormanları ve tohum mesçerelerinde ise, ana hedef habitatın korunmasından öte, genetik açıdan uygun ağaçların ekolojik hâkimiyet kurmasına yardımcı olmaktır.

Görüldüğü üzere Türkiye'de doğa koruma anlamında idari alanda çok başıııı, tanımlamalarda ise belirsizlik mevcuttur. İdari makamlarca birçok statü ve saha, korunan alan olarak değerlendiriliyor olsa da; bu statülerin birçoğunda öncelikli hedefin salt doğa koruma olmadığı; korunan alan olarak kabul edilen statülere ilişkin yapılan tanımlama ve sınıflandırmaların belirli bir standardı ve rasyonaliteyi yansıtmadığı görülmektedir. Bu kapsamda öncelikle bu sayısal çoğunluk içerisinde Türkiye'de korunan alan olarak belirlenen sahaların uluslararası standartlara göre gerçek anlamda bir koruma statüsü olup olmadığının veya koruma statülerinin, derecelerinin uluslararası standartlar çerçevesinde belirlenmesi gerekmektedir. Ancak bu önemli soruna ilişkin değerlendirme makalede belirlenen çalışma alanının dışında olup daha kapsamlı bir çalışmayı gerektirmektedir.

Seçilen sorunsal çerçevesinde makale kapsamında korunan alanlara ilişkin değerlendirme 2873 sayılı kanun uyarınca ilan edilen korunan alanlar esas alınarak yapılmıştır. Bu değerlendirme hem ulusal mevzuata uyum anlamında, hem de korunan alanlarla ilgili olarak en yaygın ve kabul görmüş standart sistemi olarak kabul edilen IUCN'in tanımladığı sistematik çerçevesinde yapılacaktır. Bu şekilde korunan alanlarda meydana gelen sayısal değişimlerin nitelik anlamında nasıl bir sonuç ortaya koyduğu tespit edilmeye çalışılacaktır.

\section{IUCN Kriterleri Doğrultusunda 2873}

Sayılı Kanun Kapsamında Belirlenen Korunan Alanlarının Koruma Önceliklerinin Değerlendirilmesi

Doğa koruma alanında teknik ve kapasite geliştirmeye yönelik faaliyet gösteren ve bilimsel çalışmalar yapan IUCN (https:// www.iucn.org/about, 23.07.20।8) “doğanın ve ilişkili ekosis- tem hizmetleri ve kültürel değerlerin uzun vadeli korunması amacıyla açıkça tanımlanmış coğrafi sınırları olan, tanınmış, adanmışlık içeren ve yasal veya diğer etkin yöntemlerle yönetilen alan" biçiminde tanımladığı korunan alanları (Dudley, 20।3: 8) 6 kategori içerisinde değerlendirmiştir. Bu kategorik sınıflandırma, temelde koruma önceliği, alan büyüklüğü ve korunacak varlığın (ekosistem, biyolojik çeşitlilik, alan vb.) yapısına göre biçimlenmiştir.

IUCN'in ortaya koyduğu sınıflandırma içerisinde koruma amacının en üst seviyede (mutlak koruma) olduğu kategoriden, doğal kaynak kullanımının göz önüne alındığı alanlara kadar kullanım amaç ve hedefinin farklılaştığı birçok ölçekte korunan alan kategorisi belirlenmiş ve koruma kullanma ilkeleri genel anlamda ortaya konulmuştur. Oldukça kapsamlı olan bu sınıflandırma sistemi, makalenin seçtiği sorunsal çerçevesinde kolayca anlaşılabilmesi için Tablo I içerisinde özetlenmiştir.

IUCN'in ortaya koyduğu bu sınıflandırma sistemi içerisinde değerlendirildiğinde, "Bilim ve eğitim bakımından önem taşıyan nadir, tehlikeye maruz veya kaybolmaya yüz tutmuş ekosistemler, türler ve tabii olayların meydana getirdiği seçkin örnekleri ihtiva eden ve mutlak korunması gerekli olup sadece bilim ve eğitim amaçlarıyla kullanılmak üzere ayrılmış tabiat parçaları" biçiminde tanımlanan tabiatı koruma alanının, 2873 sayılı kanun kapsamındaki en üst seviyedeki koruma hedefine (mutlak koruma) sahip korunan alan olduğu görülmektedir. Bu alanlar nadir ve kırılgan ekosistemlerin bulunduğu alanlar olmaları sebebiyle, mutlak koruma hedefi doğrultusunda sadece eğitim ve bilimsel amaçlı kullanımlara izin verilen sahalar olup IUCN sınıflandırmasına göre Kategori I (a) içerisine girmektedir.

Milli parklar ise enderlik ve nadirliği barındıran kaynak değerlere sahip olan; diğer taraftan da "dinlenme ve turizm” gibi rekreatif kullanımlara olanak sağlayan alanlar olarak 2873 sayılı kanun içerisinde tanımlanmışlardır. Tabiatı koruma alanından farklı olarak, milli park alanlarında kaynak değerlerin kaybolma ve zarar görme riski (kırılganlık), tabiatı koruma alanları kadar yüksek değildir. Dolayısıyla bu alanlarda bulunan kaynak değerlerin rekreatif kullanımına, bu statüde olanak sağlanmıştır. Bu çerçevede değerlendirildiğinde milli parkların IUCN Kategori sistemi içerisinde ekolojik süreçlerle birlikte tür ve ekosistemlerin korunduğu, bilimsel çalışmalarla birlikte ziyaretçilerin rekreasyonel kullanımlarına olanak sağlayan Kategori 2 içerisinde değerlendirildiği görülmektedir.

2873 sayılı kanun içerisinde sayılan diğer bir korunan alan olarak tabiat anıtı ise ilgili kanun içerisinde "Tabiat ve tabiat olaylarının meydana getirdiği özelliklere ve bilimsel değere sahip ve milli park esasları dâhilinde korunan tabiat parçaları" biçiminde tanımlanmıştır. Belirli bir coğrafyada tabiat ve tabiat olaylarının meydana getirdiği doğa parçalarına referans vermesi sebebiyle bu alanlar, IUCN korunan alan sınıflandırma sis- 
Tablo I. IUCN korunan alan kategori listesi

\begin{tabular}{|c|c|c|}
\hline Kategori & Tanım & Amaç ve koruma kullanma ilkeleri \\
\hline Kategori & $\begin{array}{l}\text { Tabiatı Mutlak Koruma Rezervi } \\
\text { (Strict Nature Reserve) } \\
\text { Biyolojik çeşitliliği, jeolojik ve jeomorfolojik özel- } \\
\text { likleri korumak için ayrılan, ziyaretlerin, kullanım ve } \\
\text { etkilerin sıkı bir biçimde kontrol edildiği, kaynak de- } \\
\text { ğerlerinin korunmasını garanti eden korunan alan- } \\
\text { lardır. Bu tür korunan alanlar bilimsel araştırmalar } \\
\text { ve izleme faaliyetleri için vazgeçilmez alanlardır. }\end{array}$ & $\begin{array}{l}\text { - Alanı insan müdahalesinden mutlak şekilde uzak tutmak/korumak } \\
\text { - Ekosistemlerin, türlerin ve jeolojik özelliklerin bozulmasını engelle- } \\
\text { mek ve mümkün olduğunca insan faaliyetlerinin etkisinden korumak, } \\
\text { - Tüm önlenebilir erişimlerin dışında doğal çevre ile ilgili bilimsel çalış- } \\
\text { malar, çevresel izleme ve eğitim için örnek bir alan sunmak, } \\
\text { - Doğa ile ilişkili kültürel ve dini değerleri korumak, } \\
\text { - Bölgesel, ulusal ya da küresel ölçekteki ekosistemleri, türleri ve jeo- } \\
\text { lojik özellikleri korumak. }\end{array}$ \\
\hline $\begin{array}{l}\text { Kategori } \\
\text { I(B) }\end{array}$ & $\begin{array}{l}\text { Yabanıl Saha (Wilderness Area) } \\
\text { Değişime uğramamış ya da çok az değişime uğra- } \\
\text { mış, doğal özelliklerini muhafaza eden, insan yer- } \\
\text { leşimlerinin olmadığı ve doğal koşulları korumak } \\
\text { amacıyla yönetilen korunan alanlardır. }\end{array}$ & $\begin{array}{l}\text { - Yerel halkın yabanıllık temelli yaşam biçimlerinin ve geleneklerinin } \\
\text { sürdürülebilmesi için koruma hedefleriyle uyumlu olacak şekilde } \\
\text { mevcut kaynakların düşük yoğunlukta kullanılmasını sağlamak, } \\
\text { - Yerel ya da yerel olmayan halka ıssızlık, gizlilik, atalara saygı gibi mad- } \\
\text { di olmayan yararlar sağlanması için ilgili kültürel ve dini değerleri } \\
\text { korumak, } \\
\text { - Yabanıl alanların dışında yürütülemeyen eğitim ve bilimsel araştırma- } \\
\text { lara izin vermek. }\end{array}$ \\
\hline Kategori 2 & $\begin{array}{l}\text { Milli Park (National Park) } \\
\text { Büyük ölçekteki ekolojik süreçlerle birlikte barın- } \\
\text { dırdığı türlerin ve ekosistemlerin, çevresel ve kül- } \\
\text { türel değerlerin korunduğu; bilimsel araştırmalara, } \\
\text { eğitim çalışmalarına, rekreasyonel faaliyetlere ve zi- } \\
\text { yaretçilere olanaklar sağlayan büyük oranda doğal } \\
\text { ya da doğala yakın alanlardır. }\end{array}$ & $\begin{array}{l}\text { - Fizyocoğrafik bölgeleri temsil eden örneklerin bulunduğu, biyotik } \\
\text { topluluklar, genetik kaynaklar ve bozulmamış doğal süreçleri içeren } \\
\text { alanların mümkün olduğunca doğal bir halde kalmasını sağlamak, } \\
\text { - Geniş ölçekteki türler, bölgesel ekolojik süreçler ve göç yollarının } \\
\text { korunmasına katkı sağlamak, } \\
\text { - Doğal kaynakların biyolojik ve ekolojik açıdan bozulmalarına neden } \\
\text { olmayacak seviyede kültürel, eğitim, rekreasyonel faaliyetleri düzen- } \\
\text { lemek için ziyaretçi yönetimini gerçekleştirmek. } \\
\text { - Yerli ve yerel halkın ihtiyaçlarını temel yönetim amaçlarıyla ters düş- } \\
\text { meyecek bir biçimde düzenlemek, } \\
\text { - Turizm aracılığı ile yerel ekonomiye katkı sağlamak, }\end{array}$ \\
\hline Kategori 3 & $\begin{array}{l}\text { Tabiat Anıtı (Nature Monumet or Feature) } \\
\text { Bir arazi biçimi, denizel bir dağ, deniz altı mağarası, } \\
\text { mağara ya da tarihi ağaçlık gibi özel tabiat anıtları- } \\
\text { nı korumak için ayrılan alanlardır. Bu tip korunan } \\
\text { alanlar yüksek ziyaretçi değerine sahip ve genellikle } \\
\text { küçük olan alanlardır. }\end{array}$ & $\begin{array}{l}\text { - Temsili, eşsiz, manevi ve doğal değerleri bulunan alanların, çarpıcı } \\
\text { doğal özelliklerinin sonsuza dek korunmasını sağlamak } \\
\text { - Alanın özelliğiyle zıtlık oluşturan ve alanda önemli değişikliğe uğra- } \\
\text { mış karasal ve denizel peyzajlarda biyolojik çeşitliliğin korunmasını } \\
\text { sağlamak, } \\
\text { - Biyolojik çeşitlilik değerine sahip dini, kültürel değerleri içeren özel } \\
\text { doğal alanları korumak, } \\
\text { - Alanın geleneksel dini ve kültürel değerlerini korumak. }\end{array}$ \\
\hline Kategori 4 & $\begin{array}{l}\text { Habitat/Tür Yönetim Alanı (Habitat/ } \\
\text { Species Management Area) } \\
\text { Belirli türleri ve habitatları korumak amacıyla yöneti- } \\
\text { len alanlardır. Bu kategoride yer alan korunan alanlar, } \\
\text { kategorinin bir gerekliliği olmamasına rağmen belirli } \\
\text { türlerin ya da habitatların devamlılığını sağlayan dü- } \\
\text { zenli etkin yönetim müdahalelerine ihtiyaç duyar. }\end{array}$ & $\begin{array}{l}\text { - Türleri ve habitatları koruyarak devamlılığını sağlamak, } \\
\text { - Geleneksel yönetim yaklaşımları ile vejetasyon elemanlarını ya da } \\
\text { diğer biyolojik özellikleri korumak, } \\
\text { - Karasal ya da denizel peyzaj koruma stratejisinin bir parçası olarak } \\
\text { habitat parçalarını korumak, } \\
\text { - Kamusal eğitim, ilgili tür ve habitatları geliştirmek, } \\
\text { - Doğayla düzenli etkileşim sağlayan şehir yerleşimleri sağlamak. }\end{array}$ \\
\hline
\end{tabular}


Tablo I (devamı). IUCN korunan alan kategori listesi

\begin{tabular}{|c|c|c|}
\hline Kategori & anım & Amaç ve koruma kullanma ilkeleri \\
\hline ategori 5 & $\begin{array}{l}\text { Peyzaj Koruma Alanı } \\
\text { (Protected Landscape/Seascape Area) } \\
\text { İnsan ve doğa etkileşiminin olduğu, önemli eko- } \\
\text { lojik, biyolojik, kültürel ve manzara değeri taşıyan } \\
\text { alanlardır. Doğa koruma ve diğer değerlerle ilişkili } \\
\text { olan unsurların korunarak alanın sürdürülebilirliğini } \\
\text { sağlama konusunda insan ve doğa etkileşiminin bü- } \\
\text { tünlüğünü sağlanması bakımından önemli alanlardır. }\end{array}$ & $\begin{array}{l}\text { - Karasal ve denizel peyzajları ve ilgili geleneksel yönetim yaklaşımla- } \\
\text { rı, toplumlar, kültürler ve dini değerleri koruyarak doğa ve kültürel } \\
\text { değerler arasında dengeli bir etkileşim sağlamak ve halkın aktif katı- } \\
\text { lımını destekleyecek bir sistem oluşturmak } \\
\text { - Türler ve ilgili kültürel peyzajları, koruma fırsatları sağlayarak geniş } \\
\text { ölçekli bir koruma sağlamak. } \\
\text { - Rekreasyon ve turizm gibi eğlence, refah ve sosyo-ekonomik faali- } \\
\text { yetler konusunda imkânlar yaratmak. } \\
\text { - Doğal ürünler ve ekosistem hizmetleri sağlamak. } \\
\text { - Tarımsal ve sucul biyolojik çeşitliliğin korunmasına destek olmak. }\end{array}$ \\
\hline Kategori 6 & $\begin{array}{l}\text { Doğal Kaynakların Sürdürülebilir } \\
\text { Kullanımına Yönelik Alanlar (Protected Area } \\
\text { With Sustainable Use of Natural Resources) } \\
\text { Ekosistem ve habitatlarla ilişkili kültürel değerler, } \\
\text { geleneksel kaynak yönetim sistemleri ile yönetilen } \\
\text { ve genellikle büyük boyutlardaki korunan alan- } \\
\text { lardır. Alanın büyük bir bölümünde doğal şartlar } \\
\text { hâkimken diğer bölümünde doğa koruma ile uyum- } \\
\text { lu bir biçimde düşük seviyede endüstriyel olmayan } \\
\text { doğal kaynak kullanımı gerçekleşmektedir. }\end{array}$ & $\begin{array}{l}\text { - Ekonomik, sosyal ve ekolojik boyutları da göz önünde bulundurula- } \\
\text { rak sürdürülebilir kullanımı desteklemek. } \\
\text { - Doğa koruma ile bağlantılı olan sosyal ve kültürel yaklaşımlarla diğer } \\
\text { kültürel yaklaşımları, inanç sistemlerini ve dünya görüşlerinin bütün- } \\
\text { leştirilmesini sağlamak. } \\
\text { - Ulusal, bölgesel ve yerel ölçekte sürdürülebilir kalkınmaya katkı sağ- } \\
\text { lamak (özellikle korunan alandaki doğal kaynaklara bağı olan yerli ve } \\
\text { yerel halk). } \\
\text { - Doğal kaynakların korunması ve sürdürülebilir kullanımı ile ilgili ola- } \\
\text { rak bilimsel araştırma ve çevresel izleme olanakları yaratmak, } \\
\text { - Küçük ölçekli turizm ve rekreasyon imkanları yaratılmasına olanak } \\
\text { tanımak. }\end{array}$ \\
\hline
\end{tabular}

Tablo, IUCN https://www.iucn.org/theme/protected-areas/about/protected-area-categories ve Thomas L. (2006) Türkiye Korunan Alan Yönetiminde IUCN Kategori Sistemi kitabından derlenerek hazırlanmıştır.

temi çerçevesinde "özel tabiat anıtlarını korumak için ayrılan yüksek ziyaretçi değerine sahip" doğa parçalarını tanımlamak için kullanılan Kategori 3 içerisinde aynı adla tanımlanmışır.

Tabiat parkları ise 2873 sayılı kanun içerisinde sayılan korunan alan statüleri içerisinde; koruma hedefinin en alt seviyede tutulduğu korunan alan statüsü olarak yer almıştır. 2873 sayılı kanun çerçevesinde "Bitki örtüsü ve yaban hayatı özelliğine sahip, manzara bütünlüğü içinde halkın dinlenme ve eğlenmesine uygun tabiat parçaları" biçiminde tanımlanan tabiat parklarında esas hedefin korumadan öte rekreasyonel kullanım olduğu açıktır. Bu sebeple korunan alanlara dair ortaya konulan sınıflandırma sistemlerinde tabiat parklarının yerini diğer statüler kadar net şekilde belirlemek kolay değildir. Çünkü tabiat parkları ile ilgili olarak ortaya çıkan temel problem, bu alanların rekreasyon öncelikli kullanımı sebebiyle korunan alanlarla ilgili bir sınıflandırma tablosu içerisinde yerinin netleşememesinden kaynaklanmaktadır. Bu çalışma içerisinde tanımı ve kullanım amacı doğrultusunda tabiat parkları, IUCN kategori sistemi içerisinde biyolojik çeşitlilik ve ekosistem zenginliğinden öte peyzaj değerlerine vurgu yapan ve "halkın aktif kullanımı" ile birlikte "rekreasyon ve turizm gibi eğlence, refah ve sosyo-ekonomik faaliyetlere" olanak sağlayan kategori 5 içerisinde değerlendirilmiştir.

Görüldüğü üzere Türkiye'de 2873 sayılı Milli Parklar Kanunu uyarınca ilan edilen korunan alanların her birinin koruma önceliği ve koruma hedefleri birbirinden oldukça farklıdır. Dolayısıyla korunan alanlara ilişkin değerlendirmelerin salt sayısal veriler üzerinden ve toptancı şekilde yapılmasının doğa koruma hedefi açısından eksik ve yanlıs sonuçlara yol açacağı kesindir. Türkiye özelinde de gerçek anlamda bir değerlendirme yapabilmek için nicel değişimlerin nitel olarak ne anlama geldiğinin, standartlar çerçevesinde ortaya konulması gerekmektedir.

\section{2873 Sayılı Milli Parklar Kanunu Uyarınca İlan Edilen Korunan Alanların 2002-2018 Arası Değişimi}

Bu bölüm içerisinde IUCN sınıflandırmasına göre koruma öncelikleri belirlenen tabiatı koruma alanı, milli park, tabiat parkı ve tabiat anıtlarının 2002-2018 arası değişimi incelene- 


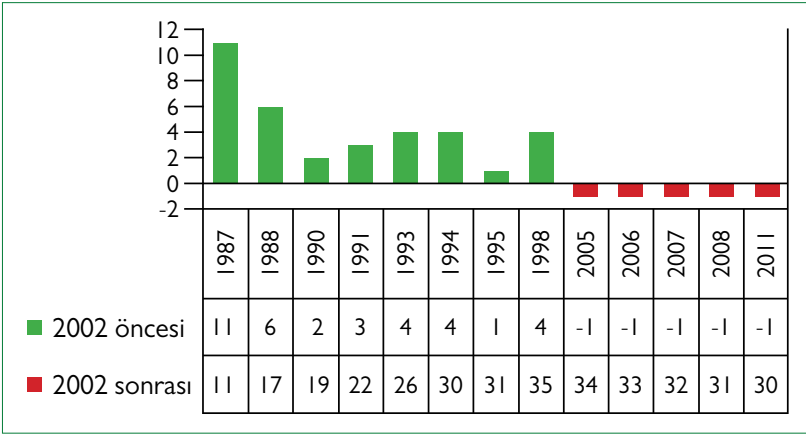

Şekil I. Yıllar itibari ile ilan ve iptal edilen TKA sayıları (Kaynak: Orman ve Su İşleri Bakanlığı arşivi.

cektir. Bu değerlendirme içerisinde ilgili korunan alanların sayısal değişimi ile beraber, IUCN kategori sitemi çerçevesinde bu sayısal değişimin, toplamda koruma hedefi doğrultusunda gerçekten nitelikli bir artışa işaret edip etmediği ortaya konulmaya çalısıllacaktır. Bu amaçla korunan alanlar belirlenirken göz önünde bulundurulan öncelikli kriterler olarak ortalama alan büyüklükleri, kaynak değer ve ekosistem zenginliği gibi değişkenler üzerinden değerlendirmeler yapılacaktır.

\section{I. 2002-20I8 Arası Tabiatı Koruma Alanlarının Değişimi}

Önceki bölümde aktarıldığı üzere ulusal mevzuattaki tanımı ile örtüşür biçimde IUCN kategori sistemi içerisinde koruma önceliği en yüksek olan ve bu doğrultuda insan kullanımının en üst düzeyde kısıtlamaya tabi tutulduğu alan tabiatı koruma alanıdır. Bu kapsamda ele alındığında 2002-20I8 arasında yeni tabiatı koruma alanının (TKA) ilan edilmediği, hatta bazı tabiatı koruma alanlarının iptal edilerek statüsünün düşürüldüğü görülmektedir. Toplam tabiatı koruma alanı sayısı 2002 yılında 35 İken 2018 yılında bu sayı 30'a düşmüştür (Şekil I).

Statüsü iptal edilen Saka Gölü Longozu Tabiatı Koruma Alanı, İstanbul'a su temini amacıyla hayata geçirilmesi düşünülen Türkiye-Bulgaristan sınırını oluşturan Rezve deresinden su temini projesinin güzergâhı içerisinde kaldığı için statüsü milli parka çevrilerek koruma önceliği düşürülmüş ve altyapı projelerinin önü açılmıştır. Statüsü düşürülen diğer alan olarak Yumurtalık Lagünü Tabiatı Koruma Alanı ise içerisinde ekolojik açıdan olduğu kadar ekonomik açıdan da önem arz eden lagün yapısını barındıran bir saha olması ve bu sahanın yöre balıkçıları tarafından yoğun biçimde kullanılması sebebiyle statüsü milli parka çevrilmiştir. Benzer şekilde Sultan Sazlığı Tabiatı Koruma Alanı; sahada sürdürülen kamış üretimi, Gala Gölü Tabiatı Koruma Alanı ise sahadaki çeltikçilik ve balıkçılık faaliyetleri sebebi ile statüsü düşürülerek milli parka dönüştürülmüştür. Bolu Sülüklü Göl Tabiatı Koruma Alanı ise yoğun rekreatif kullanımlar neticesinde statüsü iptal edilerek 20 I l yılında tabiat parkına çevrilmiştir. Bu durum IUCN sınıflandırması düşünüldüğünde oldukça radikal bir dönüşümü ifade etmektedir. OI-

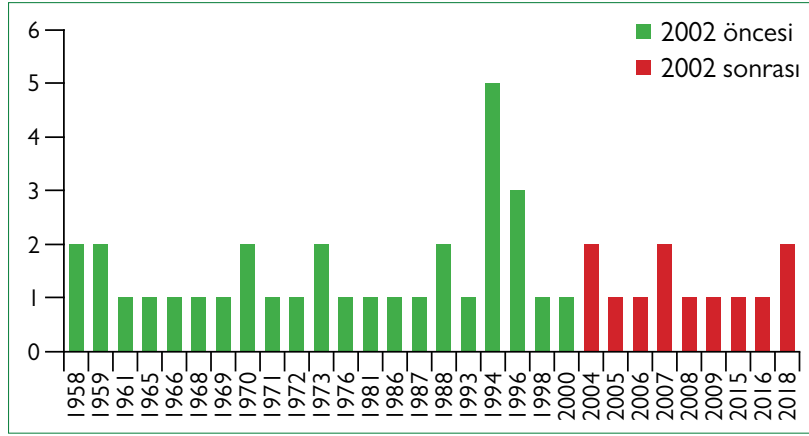

Şekil 2. Yıllara göre milli park ilan sayıları (Kaynak: Orman ve Su İşleri Bakanlığı arşivi.

dukça kırılgan habitat ve tür varlığını barındıran bir alan olarak Sülüklü Göl'ün tamamen rekreatif kullanımların öncelendiği tabiat parkına dönüştürülmesi koruma önceliğinin ne kadar göz ardı edildiğini göstermesi açısından çarpıcı bir örnektir.

\subsection{2-20I8 Arası Milli Parkların Değişimi}

IUCN sistematiği esas alındığında TKA'lardan sonra ikinci üst düzey koruma statüsü olarak tanımlayabileceğimiz milli parkların sayısı 2002-2018 arası süreç sonunda 32'den 44'e çıkmışır (Şekil 2). Niceliksel olarak bu artış yaklaşık \%38'lik bir büyümeye tekabül etmektedir. Ancak niceliksel olarak milli parklarda yaşanan bu artı̧̧ niteliksel olarak da bir artış anlamına gelmemektedir. Çünkü 2002-2018 arası yeni ilan edilen milli parklar incelendiğinde, yaşanan hızlı niceliksel artışın büyük oranda bir önceki bölümde aktarıldığı üzere tabiatı koruma alanlarının milli parka dönüştürülmesinden kaynaklandığı görülmektedir. Bu anlamda milli park sayısında artış olarak görülen bu durum, esas itibari ile IUCN kategorileri düşünüldüğünde koruma niteliğinde ve hedefinde ciddi bir düşüşe işaret etmektedir.

Milli Park ilanları nitelik olarak incelenirken ikinci olarak ele alınması gereken husus, yeni ilan edilen milli parkların ana kaynak değerleridir. 2002-20I8 arası ilan edilen 12 adet milli parkın 6 adedinin tarihi milli park olarak ilan edildiği; yani temeldeki ilan gerekçesinin doğal yapı ve karakterden çok, ortak geçmişimizde yer alan tarihi bir olay olduğu görülmektedir (Tablo 2).

Milli park tanımı incelendiğinde 2873 sayılı kanun içerisinde "milli ve milletlerarası ender bulunan tabii kültürel kaynak değerlerine" vurgu yapıldığı görülmektedir. Dolayısıyla milli park ilan süreci açısından kültürel kaynak değerlere referans vererek milli park ilan edilmesinin ulusal mevzuat açısından herhangi bir sakıncası yoktur. Ancak 16 yıllık bir süre boyunca 12 adet milli park ilanından sadece Ağrı Dağı Milli Parkı ve Tek Tek Dağları Milli Parkı'nın doğal kaynak değerlerine referansla gerçekleştiği düşünüldüğünde, doğa koruma alanındaki politik hassasiyetin ve kaygının ne kadar azaldığı net olarak görülmektedir. Bu iki milli park içerisinde yer alan Tek Tek Dağları Milli 
Tablo 2. 2002-20। 8 arası ilan edilen milli parklar ve kaynak değerleri tablosu

\begin{tabular}{llcc}
\hline Milli parkın adı & İlan tarihi & Kaynak değer & Yeni ilan/Statü değişikliği \\
\hline Sarıkamış Allahu Ekber Dağları Milli Parkı & 19.10 .2004 & Tarihi ve doğal & Yeni ilan \\
Ağrı Dağı Milli Parkı & 17.11 .2004 & Doğal & Yeni ilan \\
Gala Gölü Milli Parkı & 05.03 .2005 & Doğal & TKA iptali \\
Sultan Sazlığı Milli Parkı & 17.03 .2006 & Doğal & TKA iptali \\
Tek Tek Dağları Milli Parkı & 29.05 .2007 & Doğal & Yeni ilan \\
İğneada Longoz Ormanları Milli Parkı & 13.11 .2007 & Doğal & TKA iptali \\
Yumurtalık Lagünü Milli Parkı & Doğal & TKA iptali \\
Nene Hatun Tarihi Milli Parkı & Tarihi & Yeni ilan \\
Sakarya Meydan Muharebesi Tarihi Milli Parkı & 06.12 .2008 & Tarihi & Yeni ilan \\
Kop Dağı Müdafaası Tarihi Milli Parkı & 06.06 .2009 & Tarihi & Yeni ilan \\
Malazgirt Meydan Muharebesi Tarihi Milli Parkı & 15.11 .2016 & Tarihi & Yeni ilan \\
İstiklal Yolu Tarihi Milli Parkı Tarihi Milli Parkı & 02.11 .2018 & Tarihi & Yeni ilan \\
\hline
\end{tabular}

Kaynak: Orman ve Su İşleri Bakanlığı Arşivi.

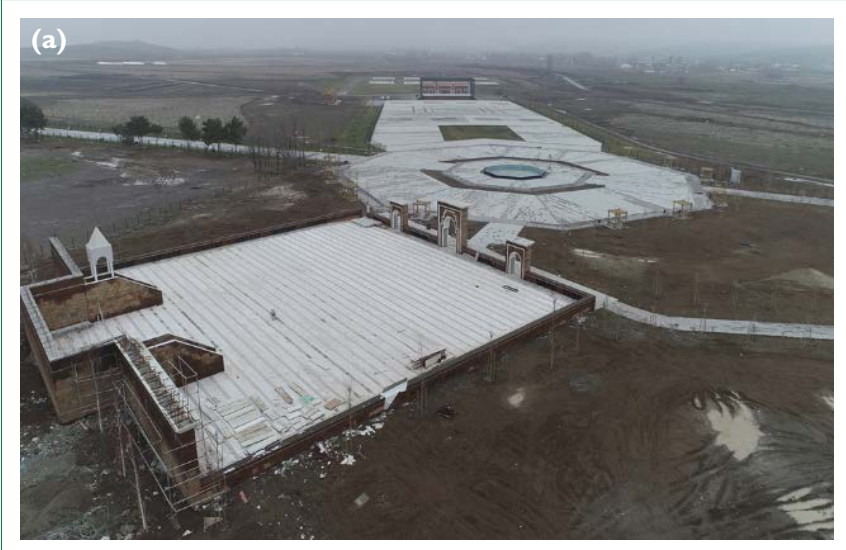

Şekil 3. Malazgirt Tarihi Milli Parkı miting alanı ve protokol ünitesi.

Parkı'nın ise barındırdığı kaynak değerlerin azlığı göz önüne alındığında milli park olabilecek bir saha olmadığı rahatıkla tespit edilebilmektedir. Bu tespiti ispatlar biçimde alana ilişkin hazırlanan plan paftasında koruma hedefi en yüksek iki bölge olan mutlak koruma ve hassas koruma bölgesinin bulunmadığı görülmektedir. Benzer doğrultuda hazırlanan plan raporu içerisinde de "Tek Tek Dağları Milli Parkı bu özellikleri ile korunan alanlar tanımlarına uymamaktadır. Bu nedenle, Tek Tek Dağları Milli Parkı'nın milli park statüsünün kaldırıması önerilmektedir" (UDGP, s.36) ifadesi bulunmaktadır. Korunan alan olarak ilan edilen bir sahanın bu saha özelinde hazırlanan plan içerisinde statüsünün iptal edilmesinin önerilmesi, ilan edilen sahanın niteliksizliğini göstermesi açııından çarpıcı bir örnektir.

Milli parklardaki nitelik açısından değişimi gözlemleyebileceğimiz üçüncü kriter ise alan büyüklüğüdür. 2002 öncesinde ilan edilen 32 adet milli parkın alan büyüklükleri ortalaması 20.142 hektar iken, 2002 sonrası ilan edilen 12 milli parkın

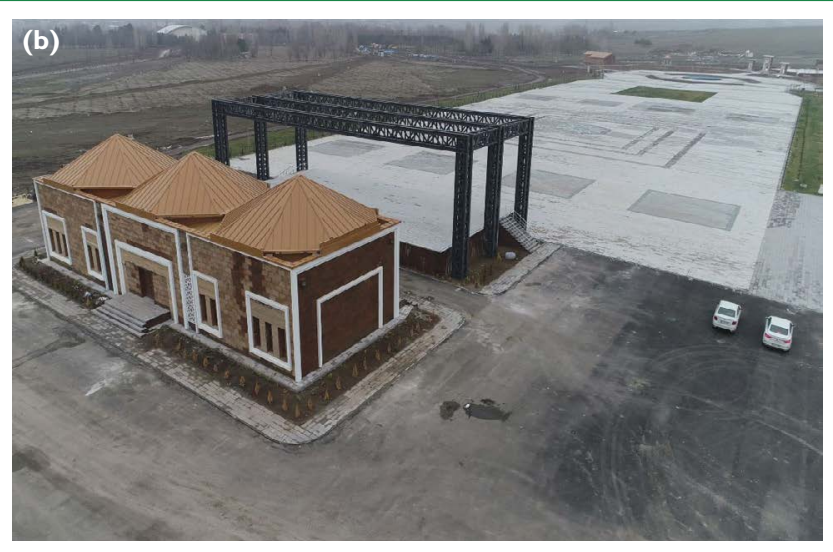

alan ortalaması 16.79| hektar olarak gerçekleşmiştir. Ortalama alan büyüklüklerinde radikal bir düşüş yokmuş gibi görünse de tarihi özelliğinden dolayı ilan edilen milli parkların alan büyüklükleri ciddi seviyede azalmıştır. Örneğin Nene Hatun Tarihi Milli Parkı 387,42 hektar, Malazgirt Meydan Muharebesi Tarihi Milli Parkı 238,83 hektar, İstiklal Yolu Tarihi Milli Parkı ise 235,7 hektar gibi bir milli park için oldukça düşük sayılabilecek yüzölçümüne sahip alanlar dâhilinde ilan edilmişlerdir. Bunun yanında bu üç saha ulusal harp tarihi açısından belirli bir harekâtı anlayabilmemize olanak veremeyecek düzeyde az tarihi kalıntıyı içerisinde barındırmaktadır. Örneğin Nenehatun Tarihi Milli Parkı sınırları içerisinde sadece 2 adet topçu tabyası ve bonetler mevcut iken; Malazgirt Meydan Muharebesi Tarihi Milli Parkı sınırları dâhilinde ise herhangi bir tarihi kalıntıya rastlamak mümkün değildir. Bu milli park içerisinde toplanma mekânı olarak meydan, protokol için helikopter pistleri ve dinlenme üniteleri gibi tamamen yapay ve sadece tek bir gün için kullanıma odaklanmış yapılar inşa edilmiştir (Şekil 3). 


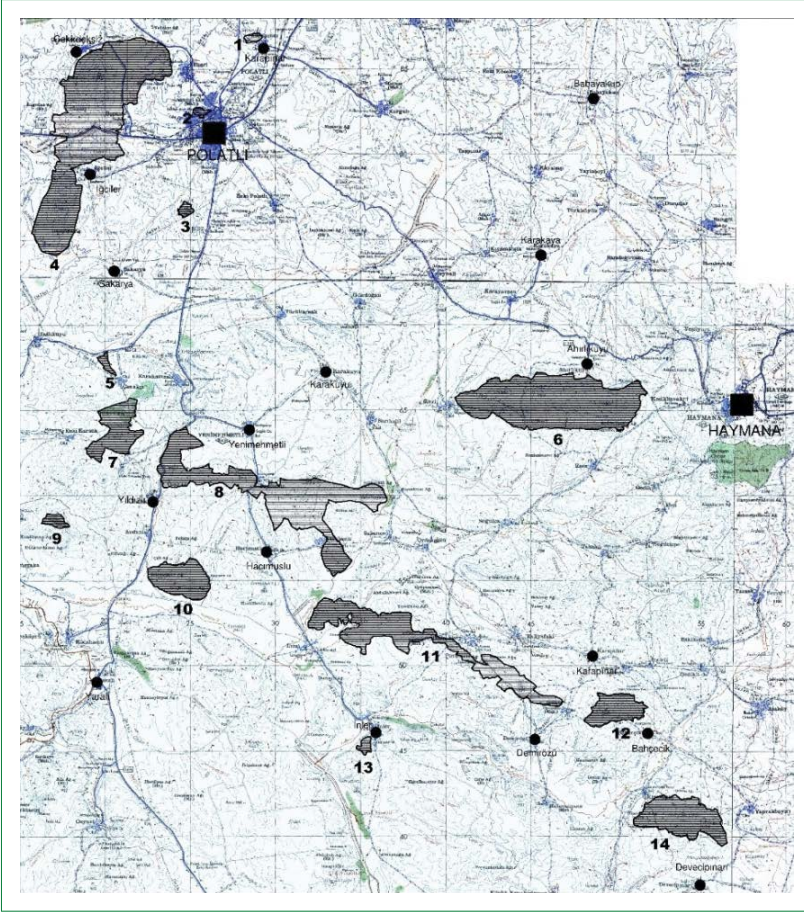

Şekil 4. Sakarya Muharebesi Tarihi Milli Parkı sınırları.

Aynı şekilde Kurtuluş Savaşı mücadelesi içerisinde oldukça önemli bir yeri ve tarihi anlamı olan İnebolu Limanı ile Ankara arasındaki silah sevkiyatının yapıldığı yaklaşık 60 km'lik hat İstiklal Yolu Tarihi Milli Parkı olarak ilan edilmiştir. İlan edilen bu milli park, çoğunluğu 20 metre genişliğinde uzanan yol güzergâhından oluşmaktadır. Bu hat her ne kadar ulusal kurtuluş savaşımız açısından önemli bir güzergâhı belirtse de gerek tarihi kalıntıların azlığı, gerekse fiziki büyüklük ve alan bütünlüğü anlamında milli park kriterlerinden oldukça uzak bir sahadır. Oysa 2002 öncesi ilan edilen Gelibolu Yarımadası Tarihi Milli Parkı (33439 ha.) ve Başkomutan Tarihi Milli Parkı (34.833 ha) hem alan büyüklükleri hem de alanda mevcut bulunan siper, mevzi, batarya, silah, tarihi kalıntılar sayesinde dönemin koşullarını ve harp tarihini anlamamıza olanak sağlayan sahalardır.

İlan edilen diğer tarihi milli park olarak Sakarya Meydan Muharebesi Tarihi Milli Parkı ise bugüne kadar en parçalı şekilde ilan edilmiş milli park sahası olmuştur. Harp tarihimiz ve ulusal kurtuluş mücadelemiz açısından çok büyük önem arz eden bu geniş alanda mevzi ve şehitliklerin olduğu kısımları içine alacak şekilde 14 parçadan oluşan alan milli park olarak ilan edilmiştir. Milli park sahalarının ilan sürecinde, özel mülkiyet harici alanlarda ilan edilmesi gibi bir yasal zorunluluk yokken, ulusal kurtuluş savaşımızın en önemli dönemeçlerinden birinin yaşandığı ve kültürel olarak birçok izin hala görülebildiği bu alan, özel mülkiyetleri milli park sınırı dışında bırakmak ve ilan sahasını minimum düzeyde tutmak için parçalı şekilde ilan edilmiştir (Şekil 4). Ancak bu kadar parçalı bir yapının milli park sahasında yönetim sorunu yaratması beklenen bir durumdur.

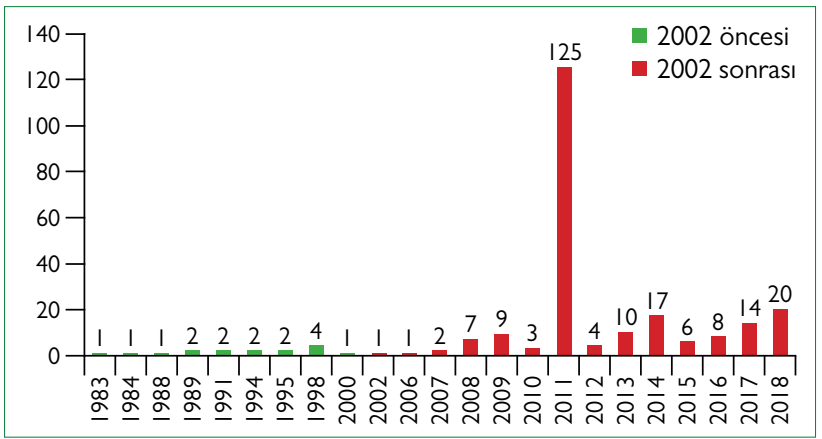

Şekil 5. Yıllara göre tabiat parkı ilan sayıları (Kaynak: Orman ve Su İşleri Bakanlı̆̆ı arşivi.

Görüleceği üzere 2002-2018 yılları arasında ilan edilen milli parklar incelendiğinde sayısal olarak ciddi bir artışın olduğu; ortalama alan büyüklüklerinde ise 2002 öncesi ortalamalarına yakın bir büyüklüğün ilan süreçlerinde korunduğu tespit edilmiştir. Ancak ilan edilen sahalar nitelik olarak incelendiğinde doğal kaynak varlığından ötürü ilan edilen milli park sayısının oldukça sınırlı olduğu görülmektedir. Tarihi milli parkların ise alan büyüklükleri ile beraber parçalı yapılarının ve arazide tarihe referans veren çok az sayıda kültürel varlı̆̆ı barındırmaları sebebiyle gerçek anlamda bir tarihi milli park olma özelliğini yansıtmadıkları açıktır.

\subsection{2-20।8 Arası Tabiat Parklarının Değişimi}

Diğer korunan alanlarla kıyaslandığında insan kullanımına en üst düzeyde olanak sağlayan tabiat parkları; 2002-20।8 arası süreçte, hem niteliksel hem de niceliksel anlamda en dramatik değişime uğramış korunan alan statüsü olmuşlardır. Niceliksel açıdan incelendiğinde, tabiat parkları ile ilgili olarak en radikal değişikliğin 201 I yılında gerçekleştiği görülmektedir. 201 I yılında Bakan Olur'u ile mesire yeri olarak kullanılan, 15 adedi sonradan iptal edilen 139 sahanın tamamı tabiat parkı haline getirilmiştir (Şekil 5). İdari açıdan bu düzenleme nitelik açısından yeni ilan edilecek tabiat parklarında radikal bir kırılma yaratmıştır. Öncesinde klasik anlamda insanların yeme-içme (piknik) ihtiyacının karşılanmasına yönelik olarak kurgulanan mesire yerlerinden farklı bir rekreasyon anlayışının temsil edildiği tabiat parkları, bu farklılıklarını yaratan özelliklerini yitirmişler, tabiat parkı anlayışı ile mesire yeri anlayışı birbirine karışır hale gelmiştir.

İlgili yönetmelik içerisinde mesire yeri "toplumun çeşitli dinlenme, eğlenme ve spor ihtiyaçlarını karşılamak, yurdun güzelliğine katkı sağlamak ve turistik hareketlere imkân vermek maksadıyla, gerekli yapı, tesis ve donatılarla kullanıma ayrılan, halkın günübirlik veya geceleme ihtiyaçlarını karşılayan, rekreasyonel ve estetik kaynak değerlerine sahip orman rejimine tabi sahalar" biçiminde tanımlanmıştır (Mesire Yerleri Yönetmeliği, RG. Tarih: 05.03.20I3, RG Sayı: 28578). Bu tanımdan anlaşılacağı üzere mesire yerleri, tabiat parkları ile karşılaştırıl- 
Tablo 3. 2002 öncesi ilan edilen tabiat parklarının ekosistem yapısı ve kaynak değerleri

\begin{tabular}{|c|c|c|c|c|}
\hline ìli & İlçesi & Adı & Büyüklük (Ha) & Ekosistem yapısı ve kaynak değer \\
\hline Muğla & Fethiye & Ölüdeniz Kıdrak & 24.58 & Deniz, orman, kumul \\
\hline Çorum & Merkez & Çatak & 379.16 & Orman \\
\hline Bolu & Mudurnu & Abant Gölü & 1262.23 & Göl ve orman \\
\hline Isparta & Sütçüler & Yazılı Kanyon & 599.87 & Kanyon, orman, arkeolojik sit \\
\hline Trabzon & Çaykara & Uzungöl & 1642.01 & Göl, orman \\
\hline Antalya & Aksu & Kurşunlu Şelalesi & 596.54 & Şelale \\
\hline Isparta & Merkez & Isparta Gölcük & 5888.05 & Göl ve orman \\
\hline Aydın & Söke & Bafa Gölü & I I 842.07 & Göl, arkeolojik sit \\
\hline İstanbul & Beykoz & Polonezköy & 2931.31 & Orman, kültürel yapı \\
\hline Balıkesir & Ayvalık & Ayvalık adaları & 19624.26 & $\begin{array}{l}\text { Arkeolojik ve tarihi sit, deniz, } \\
\text { orman (maki vejetasyonu) }\end{array}$ \\
\hline Kocaeli & Gebze & Ballıkayalar & 1602.97 & Orman, kanyon \\
\hline Kocaeli & Merkez & Beşkayalar & 1099.82 & Orman, kanyon \\
\hline İstanbul & Sariyer & Türkmenbaşı & 6.39 & Orman \\
\hline Konya & Seydişehir & Kocakoru Ormanı & 330.79 & Orman \\
\hline Gümüşhane & Torul & Artabel Gölleri & 5819.86 & Buzul gölleri ve alpin çayırlıklar \\
\hline Denizli & Çivril & Akdağ & 14692.33 & Orman, kanyon \\
\hline Artvin & Borçka & Borçka Karagöl & 368.20 & Göl ve orman \\
\hline
\end{tabular}

dığında tek bir ekosistemin (orman) hâkim olduğu ve bu ekosistemin koruma hedefinden daha çok halkın dinlenme ve eğlence faaliyetlerine yönelik olarak kullanıma açıldığı alanlardır. Bu çerçevede tabiat parkları hem tanım hem de ziyaretçiler tarafından kullanım ve algılanış biçimleri bakımından mesire yerlerinden oldukça farklı mekânsal kurguya sahip alanlardır.

Milli Parklar Kanunu'ndaki tabiat parkı tanımını geliştirecek biçimde tabiat parklarına ilişkin kriterler Milli Parklar Yönetmeliği'nin 6. Maddesi içerisinde şu şekilde açıklanmıştır: "I- Milli veya bölge seviyesinde üstün tabii fizyocoğrafik yapıya, bitki örtüsü ve yaban hayatı özelliklerine ve manzara güzellikleri ile rekreasyon potansiyeline sahip olma[k]

2- Kaynak ve manzara bütünlüğünü sağlayacak yeterli büyüklükte olma[k]

3- Bilhassa açık hava rekreasyonu yönünden farklı ve zengin bir potansiyele sahip olma[k]

4- Mahalli örf ve adetlerin, geleneksel arazi kullanma düzeninin ve kültürel manzaraların ilgi çeken örneklerini de ihtiva edebilme

5- Devletin mülkiyetinde olma[k]" (RG tarih 12.12.1986, Sayı: 19309)

Yukarıda görüldüğü üzere, tabiat parkını mesire yerinden ayırt eden temel özellik ilgili yönetmeliğin 6. maddesinin, 3 numaralı bendinde açık olarak belirtilmiştir. Yönetmeliğin bu maddesinde altı çizilen farklı ve zengin rekreasyon olanağını sağlayabilmek için 2002 öncesinde büyük ölçüde ulusal mevzuat ve IUCN kriterleri ile uyumlu şekilde ilan edilen tabiat parkları, mesire yerlerinden farklı olarak sadece ormanlık alanlar dâhilinde değil; denizel alanlar, kanyon yapıları, göl vb. gibi farklı ekosistem parçaları ve peyzaj unsurlarını barındıracak biçimde ilan edilmişlerdir (Tablo 3). Dolayısıyla tabiat parklarındaki peyzaj ve ekosistem zenginliği ve buna bağlı olarak bu alanlardaki rekreasyonel kullanımlar mesire yerlerinde sürdürülen rekreasyon kullanımından farklılaşmıştır. Tabiat parkları bu özellikleri ile mesire yerlerinde olduğu gibi sadece günübirlik yeme içme ve dinlenme ihtiyacının karşılandığı alanlar olmamış, kanyoning, rafting, kuş gözlem gibi doğa ile daha yakın ve içsel kullanım ilişkisinin kurulduğu alanlar olmuşlardır.

Farklı ve nitelikli biçimde daha çok doğayı içselleştirmeye ve deneyimlemeye yönelik ilan edilen tabiat parkları; 2002 öncesinde en az sayıya sahip (17 adet) korunan alan statüsü iken, 2018 yılı itibariyle 243'e varan sayısal büyüklüğüyle en yüksek sayıya sahip korunan alan statüsü haline gelmişlerdir. Ancak mesire yerlerinden dönüşüm neticesinde oluşan tabiat parklarının bu hızlı sayısal artışında büyük oranda alansal olarak oldukça küçük yüzölçümüne sahip mesire yerlerinin tabiat parkı olarak ilan edilmesi etkili olmuştur. Bu gelişmeler neticesinde ortalama alan büyüklükleri öylesine radikal şekilde düşmüştür ki 2002 öncesi ortalama tabiat parkı büyüklüğü 404I hektar iken, 2002 sonrasında bu oran 167 hektara kadar gerilemiştir. Bu yaklaşık olarak 25 kat bir küçülme anlamına gelmektedir. Dolayısıyla bu 

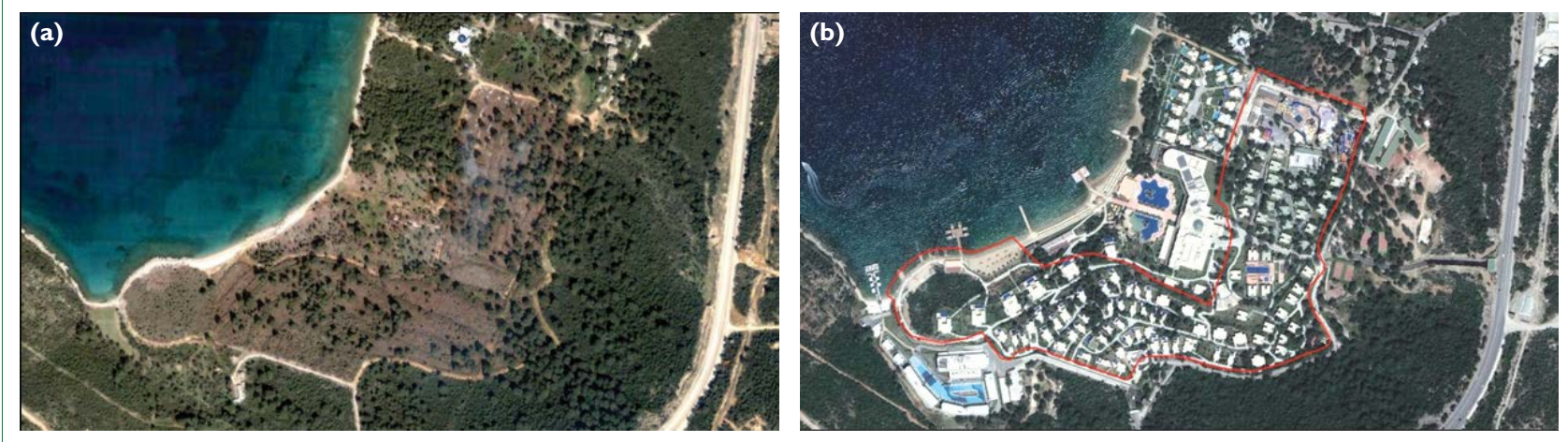

Şekil 6. Usurluk Tabiat Parkı ilan öncesi ve sonrası durum (Muğla, Bodrum).
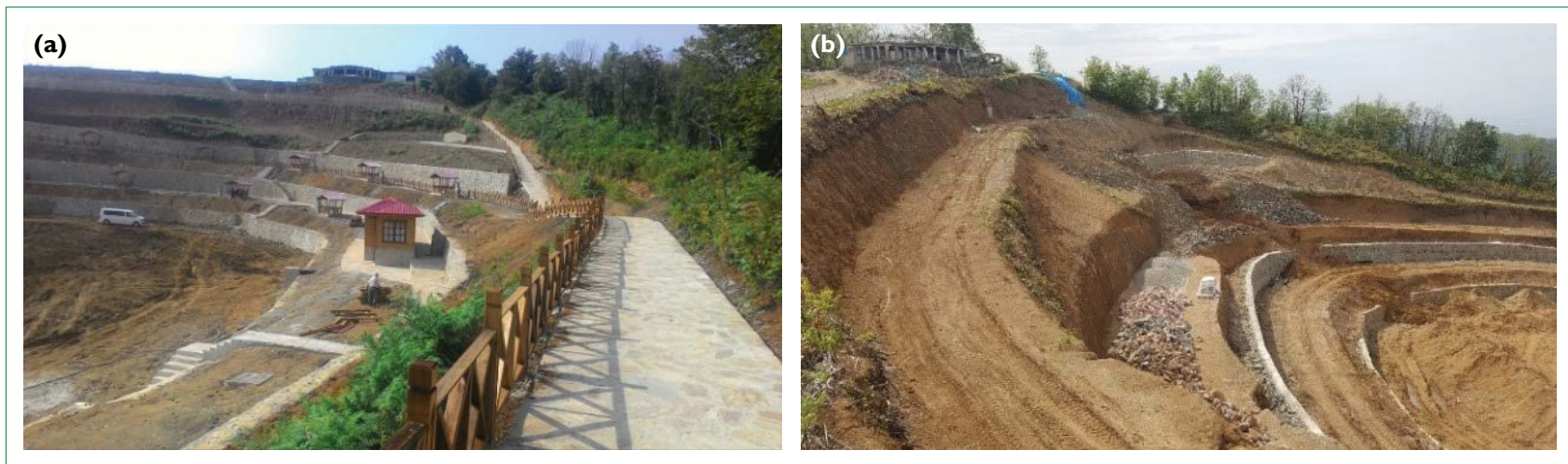

Şekil 7. Isırlık Tabiat Parkı peyzaj düzenlemesi (Rize, Merkez).

süreç içerisinde Milli Parklar Yönetmeliği'nin 6. maddesi içerisinde altı çizilen "kaynak ve manzara bütünlüğünü sağlayacak yeterli alan büyüklüğü” kriteri bu süreçte açık şekilde göz ardı edilmiş; alansal yüzölçümü kimi zaman metrekarelerle ölçülebilen sahalar tabiat parkı olarak ilan edilmeye başlanmıştır.

2002 öncesinde 100 hektardan küçük sadece I adet tabiat parkı (İstanbul, Türkmenbaşı Tabiat Parkı) mevcutken, 2002'den sonra ilan edilen tabiat parklarının I 43 adedinin 100 hektardan küçük olduğu görülmektedir. Detaylı olarak incelendiğinde de bu tabiat parklarından 8 adedinin 5 hektardan küçük, 19 adedinin 5-10 hektar arasında, 35 adedinin 10-20 hektar arasında olduğu tespit edilmektedir. Bu kadar küçük alanlar içerisinde ilan edilen tabiat parklarının IUCN kriterleri ile uyumlu ve Milli Parklar Yönetmeliği'nde belirtilen alternatif açık hava rekreasyon faaliyetlerine olanak sağlayacak belirli bir manzara bütünlüğüne sahip alanlar olamayacakları açıktır.

Yeni ilan edilen sahaların küçüklüğünün doğal sonucu olarak ekosistem ve rekreasyonel kullanım çeşitliliği ve niteliği azalmıştır. Bu süreç sonunda yeni ilan edilen tabiat parkları; mesire yerleri gibi tek tip bir ekosisteme (orman) bağlı olarak, dar bir sahada yeme-içme ağılıklı rekreasyonel kullanımların gerçekleştiği, doğa ile içsel ve derin ilişkilerin kurulmasına olanak sağlayamayacak sahalar haline dönüşmüşlerdir.
Ayrıca hem ulusal mevzuat hem de IUCN'in yaptığı tanım ve kullanım önerileri doğrultusunda karasal ve denizel peyzajları korumanın ana hedef olarak belirlendiği ve manzara bütünlügüuün rekreasyonel kullanım anlamında da en önemli kaynak değer olarak altının çizildiği bu alanlarda, 2002 sonrasındaki uygulamalarla koruma hedefinden ve belirlenen rekreasyonel kullanım hedeflerinden radikal şekilde uzaklaşımıştır. Kimi tabiat parkları; alanın yapısı, üst ölçek uygulamalarla getirilen yoğun yapılaşma kararları neticesinde tüm doğallığını kaybederken (Şekil 6), kimi tabiat parklarında ise yapılan alt ölçekli peyzaj düzenlemeleriyle alanın özgün peyzaj değeri yok edilmiştir (Şekil 7).

\subsection{2-20।8 Arası Tabiat Anıtlarının Değişimi}

2873 sayılı kanun içerisinde "tabiat ve tabiat olaylarının meydana getirdiği özelliklere ve bilimsel değere sahip ve milli park esasları dâhilinde korunan tabiat parçaları" olarak tanımlanan tabiat anıtı statüsü hem IUCN, hem de ulusal mevzuat çerçevesinde incelendiğinde; bu statünün esas itibariyle tabiat olayları (jeolojik, jeomorfolojik, hidrojeolojik, iklim değişimi vb) neticesinde oluşmuş alansal büyüklüğe sahip tabiat parçalarını tanımlamak için kullanıldığı görülmektedir. Ancak 2002-20I8 arası dönemde tabiat anıtı olarak ilan edilen I 12 yerin 96'sının anıtsal nitelikteki ağaçlardan oluştuğu görülmektedir. 2873 sayılı Milli Parklar Kanunu içerisinde bu statüye ilişkin olarak yapılan tanıma bakıldığında tabiat anıtlarının milli park esasları 


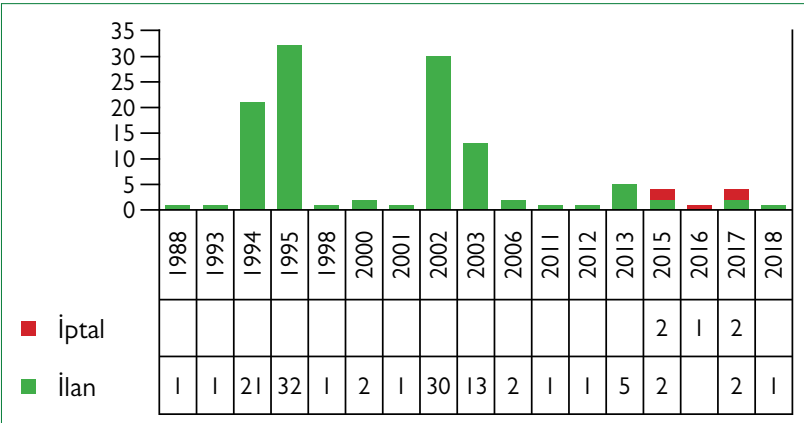

Şekil 8. Yıllar itibariyle tabiat anıtı ilan ve iptal sayıları (Kaynak: Orman ve Su İşleri Bakanlığı arşivi.

dâhilinde korunması gereken sahalar olarak tarif edildiği görülmektedir. Dolayısıyla tabiat anıtlarında noktasal bir varlıktan öte alansal bir oluşuma referans verildiği açıtıtır.

Bu anlamda tescil edilen tabiat anıtları özellikleri açısından incelendiğinde, 2003 sonrasında bu statüye ilişkin radikal bir dönüşümün yaşandığı görülmektedir. Çünkü alansal büyüklüğe sahip 16 adet tabiat anıtının Il'i 2003 sonrasında ilan edilmiştir (Şekil 8).

İlan edilen bu sahalar içerisinde Nemrut Kalderası (4804 ha) gibi hem büyüklüğüyle hem de barındırdığı doğal oluşumlar nedeniyle nadir ve anıtsal özelliğe sahip alanların yanında, Zeytintaşı ve Gilindire Mağaraları gibi hem büyüklükleri hem de mağara içi oluşumlarının özgünlüğüyle dikkat çeken sahalar bulunmaktadır. İlan edilen tüm bu sahalar hem ulusal mevzuat hem de IUCN kriterleri açısından nitelikli sahalar olup; 2002 sonrası süreçte tabiat anıtlarının tesciliyle ilgili olarak olumlu bir dönüşümün gerçekleştiğinin somut örnekleridirler.

\section{2873 Sayılı Kanun Uyarınca İlan Edilen Korunan Alanların 2002 Sonrası Süreçteki Değişiminin Avrupa Ülke Örnekleri İle Karşılaştırması}

2002 sonrası süreç Türkiye'de korunan alanlar noktasında kırılmaların yaşandığı bir dönem olmuştur. Bu dönem içerisinde Türkiye'de yaşanan dönüşümlerin rastlantısal olmadığııı ispat etmek için Türkiye'de yaşanan pratikler, diğer ülkelerdeki örnekleriyle kıyaslanmıştır. Bu çerçevede 2873 sayılı Milli Parklar Kanunu'na göre makale kapsamında değişimi incelenen korunan alanlarla, bu korunan alan statüleri ile eşleşen diğer ülkelere ait koruma statülerinin oransal artış miktarları, minimum ve ortalama alan büyüklükleri karşılaştırılmıştır.

Makale kapsamında ülkeler seçilirken koruma statülerinin benzer özellik ve nitelik göstermesine dikkat edilmiştir. Seçil- meyen Avrupa ülkelerinin bir kısmını istatistik olarak düzenli veri oluşturmayan ya da raporlama yapmayan ülkeler oluştururken; diğer kısmını ise koruma statülerindeki farklılıklar nedeniyle Türkiye ile kıyaslamaya olanak sağlamayan ülkeler oluşturmuşlardır.

Bu kapsamda Tablo 4 içerisinde Avrupa Çevre Ajansı'na üye konumda bulunan Yunanistan, İspanya, Bulgaristan, Hırvatistan, İrlanda, İtalya, Macaristan ve Slovenya'nın Avrupa Çevre Ajansı Korunan Alanlar Ortak Veri Tabanına (Common Database Designated Areas, CDDA) işledikleri veriler ile Türkiye'de korunan alanlarda 2002 sonrası süreçte meydana gelen sayısal değişimler karşılaştırılmalı olarak verilmiştir.

Ülkelerin Avrupa Çevre Ajansı'na 2002-2018 arası döneme ilişkin sundukları veriler doğrultusunda yapılan karşılaştırma neticesinde aşağıdaki hususlar tespit edilmiştir.

I. 2002-2018 arası süreçte TKA sayısında ülkelerin birçoğunda değişim yaşanmamıştır. Artışın yaşandığı ülkeler arasındaki sıralamada ise Yunanistan \%85'lik artış oranı ile birinci, Macaristan \%23'lük artış oranı ile ikinci, \%6'lık artış oranı ile İtalya ise üçüncü ülke konumuna erişmiştir. Avrupa ölçeğinde kıyaslandığı zaman TKA statüsü eşdeğerindeki korunan alanlarda azalışın yaşandığı tek ülke ise \%।4 gibi yüksek bir oranla Türkiye olmuştur.

2. Milli park statüsüne eşdeğer koruma statülerinde yapılan karşılaştırmada ise Türkiye'nin \%38'lik artışla Yunanistan'dan (\%240) sonra ikinci konumda olduğu görülmektedir.' Ancak minimum alan büyüklüğü üzerinden yapılan karşılaştırmada, Türkiye'nin 235.70 hektar büyüklük ile Avrupa'daki en küçük yüzölçümlü milli park sahasının bulunduğu ülke olduğu görülmektedir. Bu tek bir örnek üzerinden yapılan istatistiki bir değerlendirme değildir. Çünkü Avrupa'daki en küçük milli park sahası büyüklüğü 1439.13 hektar ile Yunanistan'da iken Türkiye'de 2002 sonrası ilan edilen milli parkların 3 tanesi 400 hektardan küçüktür.

3. Tabiat parklarında ise en fazla sayısal artış $\% 37$ ve $\% 40^{\prime}$ 'ık artış oranlarıyla Bulgaristan ve İspanya'da gerçekleşmişken, Türkiye'de 2002 sonrası artış \%।320 gibi spekülatif bir orana ulaşmıştır. Tabiat parkları ile ilgili olarak minimum alan büyüklüğü açısından bir değerlendirme yapıldığında Avrupa ölçeğinde en küçük alan büyüklüğüne sahip ülkenin Türkiye olduğu görülmektedir.

4. Tabiat anıtları özelinde bir kıyaslama yapıldığında ise Türkiye, 2002 sonrasında Avrupa ülkelerine benzer bir artış oranı sergilemiştir. 2002 yılından sonra ilan edilen tabiat anıtları, Avrupa'daki örneklerine benzer nitelikte alansal

Yunanistan'ın korunan alan sayısındaki bu hızlı artışın doğa koruma hedefinden öte siyasi bir içeriğe sahip olma ihtimali yüksektir. Çünkü Yunanistan son yıllarda “Egemenliği Anlaşmalarla Yunanistan'a Devredilmemiş Ada, Adacık ve Kayalıklar” kapsamında bulunan birçok adada korunan alan ilan ederek belirli adalar üzerinde bu statüler aracılığıyla hak iddia etme yoluna gitmiştir. Bu girişimlere ilişkin Türk Dışişleri Bakanlığı tarafından nota verilmiş ve Yunanistan AB Çevre Programını istismar etmekle suçlanmıştır (http://www.hurriyet.com.tr/gundem/ankaradan-yunanistana-natura-2000-uyarisi-40790567; https://www.timeturk.com/yunanistan-dan-ege-yi-isitacak-hamle/ haber-875464, http://www.milliyet.com.tr/yunanistan-in-sinsi-kardak-plani-gundem-2639372/, Erişim tarihi: 24.12.2018). 
Tablo 4. Avrupa ülkelerinde korunan alanların sayısal verilerine ilişkin tablo

\begin{tabular}{|c|c|c|c|c|c|c|c|}
\hline \multirow[t]{2}{*}{ Ülke } & \multirow{2}{*}{$\begin{array}{l}\text { Korunan } \\
\text { alan }\end{array}$} & \multirow{2}{*}{$\begin{array}{l}\text { Korunan alanın } \\
\text { bulunduğu ülkedeki } \\
\text { resmi tanımı }\end{array}$} & \multirow{2}{*}{$\begin{array}{l}\text { Ortalama } \\
\text { büyüklük }\end{array}$} & \multirow{2}{*}{$\begin{array}{l}\text { Minimum } \\
\text { büyüklük }\end{array}$} & \multicolumn{2}{|c|}{ Sayı } & \multirow{2}{*}{$\begin{array}{c}\text { Artış } \\
(\%)\end{array}$} \\
\hline & & & & & 2012 & 2018 & \\
\hline \multirow[t]{6}{*}{ Yunanistan } & TKA & Nature Reserve Area, & 2840.42 & 49.22 & 7 & 13 & 85 \\
\hline & & Absolute Nature Reserve Area & & & & & \\
\hline & MP & National Park & 56728 & 1439.13 & 5 & 17 & 240 \\
\hline & & National Marine Park & & & & & \\
\hline & TP & & - & - & - & - & - \\
\hline & TA & Naturel Monuments and Landmark & & - & 51 & 51 & 0 \\
\hline \multirow[t]{5}{*}{ İspanya } & TKA & Nature Reserve & - & - & - & - & - \\
\hline & & (Special, Wildlife, Parcial, Integral) & & & & & \\
\hline & MP & National Park & 25443.03 & 3010.61 & 12 & 15 & 25 \\
\hline & TP & Natural Park & 27258.23 & 51.08 & 93 & $|3|$ & 40 \\
\hline & TA & $\begin{array}{l}\text { Nature Monument, Nature Monument } \\
\text { (National Interest) }\end{array}$ & 344.91 & - & 154 & 250 & 62 \\
\hline \multirow[t]{4}{*}{ Bulgaristan } & TKA & Strict Nature Reserve & $|402.2|$ & 27.58 & 55 & 55 & 0 \\
\hline & MP & National Park & 64474 & 40356 & 3 & 3 & 0 \\
\hline & TP & Nature Park & 25085.9 & 1324.7 & 8 & II & 37 \\
\hline & TA & Nature Monument & 52.19 & 0.01 & 333 & 349 & 4 \\
\hline \multirow[t]{4}{*}{ Hırvatistan } & TKA & Strict Reserve, Special Reserve & 537.09 & 1.57 & 79 & 79 & 0 \\
\hline & MP & National Park & 12245.39 & 3400.49 & 8 & 8 & 0 \\
\hline & TP & Nature Park & 39277.13 & 5748.99 & 10 & II & 10 \\
\hline & TA & Naturel Monument & 2.79 & - & 74 & 81 & 9 \\
\hline \multirow[t]{5}{*}{ İrlanda } & TKA & National Nature Reserve (State Ownership) & 286.48 & 4.07 & 73 & 73 & 0 \\
\hline & & National Nature Reserve (Private Ownership) & & & & & \\
\hline & MP & National Park & 10192.96 & 1996.31 & 6 & 6 & 0 \\
\hline & TP & Special Amenity Order & - & - & - & - & - \\
\hline & TA & Nature Heritage Area & 388.8 & 21.42 & - & 155 & \\
\hline \multirow[t]{6}{*}{ İtalya } & TKA & State Nature Reserve, Regional/ & 692 & - & 479 & 512 & 6 \\
\hline & & Provincial Nature Reserve & & & & & \\
\hline & MP & National Park & 64062.2 & 3860 & 21 & 24 & 14 \\
\hline & TP & Interregional Nature Park & & & & & \\
\hline & & Regional/ Provincial Nature Park & 9661.61 & 7 & 105 & 134 & 27 \\
\hline & TA & Naturel Monument & - & - & - & - & - \\
\hline \multirow[t]{5}{*}{ Macaristan } & TKA & Nature Conservation Area, & 182.99 & 0.4 & 138 & $17 \mid$ & 23 \\
\hline & & Local Nature Conservation area & & & & & \\
\hline & MP & National Park & 48262.2 & 20200 & 9 & 10 & II \\
\hline & TP & Nature Park & $697 \mid 4.5$ & 10177 & - & 8 & \\
\hline & TA & Naturel Monument & 1.37 & 0.03 & 64 & 88 & 37 \\
\hline
\end{tabular}

Avrupa Çevre Ajansı CDDA (Common Database Designated Areas) veritabanı, 2018.

büyüklüğe sahip sahalar olmuşlardır. Örneğin Nemrut Kalderası Tabiat Anıtı büyüklük ve nitelik açısından Avrupa'daki birçok ülkedeki örnekten büyük bir saha konumundadır.
Görüleceği üzere Türkiye'de 2002 tarihini esas alarak yapılan değerlendirmelerin tamamı Avrupa ülkeleri esas alınarak yapılan kıyaslamalarda da doğrulanmış ve her bir statü için 
Türkiye özelinde yapılan değerlendirmelerin benzeri sonuçlar ortaya çıkmıştır.

\section{Sonuç}

Korunan alanlar bir yanıyla ülkeler açısından saygınlık (prestij) alanları olarak görülürken, diğer taraftan da barındırdıkları ekonomik ve ekolojik faydalar dolayısıyla büyük önem arz eden sahalar olmuşlardır. Dünya ölçeğinde de ekolojik yıkımın en önemli gündem olduğu günümüzde korunan alanlar bu gidişatı yavaşlatmanın en önemli araçlarından biri olarak görülmektedirler. Ancak korunan alanların sayısal ve alansal olarak artışının hangi ölçüde doğa koruma hedefine hizmet ettiği tüm dünyada olduğu gibi ülkemizde de tartışılan bir konudur. Bu anlamda Türkiye'de değişik çevrelerce doğa koruma alanında 2002-2018 arası sürece ilişkin neredeyse birbirinin taban tabana zıttı değerlendirmeler yapılmıştır.

Bu makale içerisinde nesnel verilere bağlı kalarak yapılan değerlendirmeler neticesinde 2002-2018 arası süreçte korunan alanlarda IUCN kriterleri uyarınca koruma hedefi en yüksekte olan alanlarda hızlı bir azalışın meydana geldiği, koruma hedefi daha düşük statülü alanlarda ise hızlı bir sayısal artışın olduğu tespit edilmiştir. Dolayısıyla korunan alanlarda toplamda sayısal artış yüksek gibi görünse de esas itibariyle bu artışın nitelikli bir artış olmadığı net olarak görülmüştür.

Ayrıca Türkiye'de korunan alanlarla ilgili en temelde tanım ve kabullerde belirsizliklerin olduğu açıktır. Bakanlıkların resmi olarak ilan ettikleri korunan alan statülerinden birçoğunda koruma hedefinin öncelenmediği, yabanıllı̆̆ ve nadirliği düşük seviyedeki alanlar içerisinde, IUCN kriterlerine uygun olmayan statüler dâhilinde korunan alanların ilan edildiği; ya da korunan alan statülerinin iptal edilerek birbirlerine dönüştürüldüğü ve mesire alanı gibi kullanımların tabiat parkı statüsüne çevrildiği bir sürecin yaşandığı görülmüştür. Yaşanan bu süreç kaçınılmaz olarak korunan alan statülerinin çoğunda koruma hedefinde bir gerileme ve muğlaklık yaratmıştır. Örneğin tabiatı koruma alanlarında kullanım baskısı nedeniyle iptaller yaşanırken, yeni milli park ilanlarında büyük oranda tarihi alanlara öncelik verilmiş; doğal nitelikli alanlar oldukça sınırlı kalmıştır. Tabiat parkları başta olmak üzere birçok korunan alanda ise koruma hedefiyle bağdaşmayan ilanlar ve buna koşut uygulamalar görülmeye başlanmıştır.

Bugün korunan alanlarda görülen bu durum esas itibariyle sermayenin birçok kentsel alanda uyguladığı önce muğlaklaştırıp, sonra itibarsızlaştırıp sonra piyasalaştırması sürecinin doğal alanlarda da yaşanmaya başladığını göstermektedir. Bu noktada korunan alanlarda toptan ve büyük ölçekli bir yıkım yaratma ihtimali yüksek olan böyle bir sürecin önüne geçebilmenin yegâne yolu, etkin bir korunan alan ağı ve yönetimini ortaya koymaktır. Bu doğrultuda korunan alan ilan ve tanımlarındaki muğlaklıkların giderilmesi en öncelikli olarak gerçekleştirilmesi gereken hedef olmalıdır.

Bu anlamda öncelikli olarak yapılması gereken mevcut statüler açısından uyumsuzluk teşkil eden sahaların tespit edilip bu alanlara ilişkin yeniden bir değerlendirme yapılmasıdır. Bu noktada IUCN'nin belirlediği korunan alan sınıfları içerisinde var olan ancak ülkemiz mevzuatında yer almayan "Tür ve $\mathrm{Ha}$ bitat Koruma Alanı”nın korunan alanlarla ilgili mevzuat içerisine alınması büyük önem arz etmektedir. Çünkü sadece belirli bir tür ve habitata yönelik korunan alan ilan edilmesi mümkün olmadığından, belirli bir habitat veya tür nedeniyle öne çıkan alanlar günümüzde IUCN sisteminde bambaşka amaçlar ve nitelikler nedeniyle ilan edilmesi gereken alanlar altında değerlendirilmek zorunda kalınmıştır.

Mevzuattaki bu eksikliğin yanında ilan edilen alanların statülerinin, bilimsel gerekçelerden uzak salt ekonomik kullanımlar gözetilerek değiştirilmesi korunan alan yönetimi açısından uygun bir yöntem değildir. Çünkü bir korunan alanın ilanında en önemli etkenler alanın biyoçeşitlilik, ekosistem ve jeomorfolojik çeşitliliği-özgünlüğü iken bu yapılarda köklü bir değişim olmaksızın; sadece belirli kullanımların önünü açabilmek amacıyla yapılan statü değişiklikleri ya da iptaller korunan alanlarla ilgili muğlaklığı artırmakta ve etkin bir yönetimi engellemektedir.

Belirlenen bu hususlar doğrultusunda gerekli adımlar atılmaz ve korunan alanlardaki süreç bu şekilde devam ederse korunan alanlarda yaşanacak itibar ve değer kaybı neticesinde bugün için birkaç örnekte meydana gelen yıkıcı uygulamaların tüm korunan alanlara yayılması ihtimalinin güçlü şekilde kendini göstereceği açıktır. 


\section{KAYNAKLAR}

Ant, H., Stipprowit, A. (1985). Natur-und Umweltschutz- ein uraltes Problem. LöflMitteilungen, 10, Heft 3, 24-26, Landwirtschaftsverlag GmbH, Münster- Hiltrup.

Bruner A. G., Gullison R., E., Rice R., E. \& Fonseca Gustavo, A.B. (2001). Effectiveness of parks in protecting tropical biodiversity. Science 291

Dudley, N. (Ed.) (2008). Guidelines for Applying Protected Area Management Categories. (Best Practice Protected Area Guidelines Series No.21) Gland: IUCN.

Eagles, PaulF.J., McCool, Stephen F. And Haynes, Christopher D.A. (2002). Sustainable Tourism in Protected Areas: Guidelines for Planning and Management. IUCN Gland, Switzerland and Cambridge

Elliott, H.B. (Ed.) (1974). Second World Conference on National Parks. Proceedings. Morges: IUCN.

Gülez, S. (1992). A Method for Evaluating Areas for National Park Status. Environmental Management, 16, 811-818.

Holdgate, M. (1999). The Green Web. London: Earthscan.

Jongman, R.H.G. (2004). The Context and Concept of Ecological Networks. R.H.G. Jongman and G. Pungetti (eds.), Ecological Networks and Greenways Concept, Design and Implementation, Cambridge University Press, Cambridge

Krishna, N., Sankar, V. B. (1997). Ekolojik Mirasın Korunması: Tamil Nadu’nun Kutsal Ağaçları. XXI. Yüzyıla Doğru Sürdürülebilir Kalkınma İçin Ormancilık, XI. Dünya Ormancllk Kongresi Bildirileri, Cilt 2, Syf.67-72.

Kurdoğlu, O. (2007). Dünyada Doğayı Koruma Hareketinin Tarihsel Gelişimi ve Güncel Boyutu, Artvin Çoruh Üniversitesi Orman Fakültesi Dergisi, 8 (1), 59-76.

Liu, J., Ouyang, Z., Miao, H. (2010). Environmental Attitudes of Stakeholders and Their Perceptions Regarding Protected Area-Community Conflicts: A Case Study in China. Elsevier, Journal of Environmental Management 91, 2254-2262.

Mace, G.M., Balmford, A., Ginsberg, J.R. (1998). Conservation in a Changing World. Cambridge University Press: Cambridge, UK.

Mesire Yerleri Yönetmeliği, Resmi Gazete 05.03.2013 tarih ve 28578 sayı.

Mulongoy, K.J.,Chape, S.P. (Eds) (2004). Protected Areas and Biodiversity: an overview of key issues.CBD Secreriat, Montreal Canada and UNEPWCMC, UK: Cambridge.

Milli Parklar Yönetmeliği, Resmi Gazete 12.12.1986 tarih ve 19309 sayı.

Philips, A. (2007). Short History of the International System of Protected Areas Manageent Categories Defining protected areas: an international conference in

Almeria, Spain. Gland: IUCN.

Thomas L. (2006). Türkiye Korunan Alan Yönetiminde IUCN Kategori Sistemi, Ankara: Çevre ve Orman Bakanlığı Yayınları.

Orman ve Su İşleri Bakanlığı (2012). Tek Tek Dağları Uzun Devreli Gelişme Planı Raporu, Ankara

Yücel M., Babuș D. (2005). Doğa Korumanın Tarihçesi ve Türkiyédeki Gelişmeler, Doğu Akdeniz Orman Araştırma Müdürlüğü (DOA) Dergisi (Journal of DOA), Sayı: 11, s: $151-175$.

WWF (2008), Etkin Korunan Alan Sistemlerine Doğru. Biyolojik Çeşitlilik Sözleşmesi Korunan Alanlar İş Programı Uygulama Kılavuzu. (Çev. Sedat Kalem), İstanbul.

Avrupa Çevre Ajansı CDDA (Common Database Designated Areas) Veritabani, 2018

Wild,R., Mc Leod, C. (2008). Sacred Natural Site: Guidelines for Protected Area Managers. Gland: IUCN.

\section{Internet Kaynakları}

https://www.iucn.org/theme/protected-areas/about/protected-area-categories

https://www.iucn.org/about

http://webdosya.csb.gov.tr/dosyalar/images/file/728_nolu_ilke_karari.pdf

http://www.mevzuat.gov.tr/MevzuatMetin/1.3.6831.pdf

http://googleearth.com

http://www.hurriyet.com.tr/gundem/ankaradan-yunanistana-natura-2000uyarisi-40790567;

https://www.timeturk.com/yunanistan-dan-ege-yi-isitacak-hamle/haber-875464,

http: / / www.milliyet.com.tr/yunanistan-in-sinsi-kardak-planigundem-2639372/ 